\title{
PERGERAKAN HARGA SAHAM SYARIAH PADA SAHAM BANK SYARIAH DILIHAT DARI FAKTOR MAKROEKONOMI
}

\author{
Rais Sani Muharrami, Shufiatul Zahidah \& Ika Yoga \\ FEBI IAIN Surakarta
}

\begin{abstract}
This study aims to determine the macroeconomic indicators that affect sharia banking stock price index period 2014-2016. Four variables consist of inflation, BI interest rate, rupiah exchange rate and SBIS are considered to have an effect on the syariah bank stock price index. This research uses quantitative method. This study uses monthly time series data which is analyzed by multiple linear regression. The data used are secondary data with 36 data from January 2014-December 2016. Data collection is taken with documentation techniques sourced from the official website of Bank Indonesia and yahoofinance.com. The results showed that inflation did not significantly influence the sharia bank stock price index. While the BI interest rate, the exchange rate of rupiah and SBIS have a significant influence on PT Bank Panin Dubai Syariah Tbk stock price index. From the results of this study, it can be concluded that the indicators considered in the PT Bank Panin Dubai Syariah Tbk stock price index are BI rate, rupiah exchange rate and SBIS.
\end{abstract}

Keywords: macroeconomic indicator, PT Bank Panin Dubai Syariah Tbk stock price

\section{A. Pendahuluan}

Persaingan usaha yang semakin ketat, menuntut para pelaku usaha untuk senantiasa meningkatkan produktifitas perusahaan. Meningkatkan sisi permodalan, menjadi pilihan yang sering dilakukan oleh para penguasaha. Salah satunya adalah dengan terjun dalam industry pasar modal. Kegiatan pasar modal tersebut terlihat dalam bentuk penghimpunan dana, investasi dengan penjualan saham dan penerbitan obligasi atau sebagai tolok ukur 
stabilitas kondisi makroekonomi (Beik \& Fatmawati, 2014: 156). Pasar modal syariah merupakan alternatif investasi menggunakan saham syariah. Saham syariah merupakan instrument investasi yang menyatakan bukti penyertaan kepemilikan dalam perusahaanperusahaan sesuai syariah.Tingkat pengembalian yang tinggi dalam investasi saham diikuti dengan tingkat risiko yang besar pula, sehingga saat berinvestasi perlu pengetahuan mengenai halhal yang mempengaruhi resiko.

Keputusan investor memilih saham sebagai investasinya membutuhkan rekap data pergerakan saham yang beredar di bursa. Informasi rekap untuk menggambarkan pergerakan harga saham adalah indeks harga saham yang memberikan informasi harga saham pada waktu tertentu. Indeks harga saham adalah catatan terhadap perubahan maupun pergerakan harga saham sejak pertama kali beredar sampai waktu tertentu (Sunariyah, 2006: 122).

Untuk saat ini pasar modal di Indonesia lebih dikenal dengan Bursa Efek Indonesia (BEI). Guna memenuhi kebutuhan pasar modal syariah, maka pada 3 Juli 2000, di Indonesia telah lahir indeks saham syariah yaitu Jakarta Islmaic Index (JII). Selain JII, terdapat indeks syariah baru yang meramaikan pasar modal syariah Indonesia yaitu Indeks Saham Syariah Indonesia (ISSI) yang diluncurkan tanggal 12 Mei 2011 oleh BEI. ISSI yaitu indeks saham yang mencerminkan keseluruhan saham syariah yang tercatat di BEI.

Sampai pada periode ini saham syariah yang terdaftar pada ISSI sebanyak 331 saham. Sayangnya dalam sektor keuangan, hanya ada satu bank syariah yang sudah listing di ISSI yaitu PT Bank Panin Dubai Syariah Tbk. Sebagaimana kita ketahui ada banyak bank syariah yang terbilang besar di Indonesia. Namun belum listing di bursa saham. Tahun 2013 sempat ada ada isu keinginan 2 bank syariah terbesar, yakni Bank Syariah Mandiri (BSM) dan Bank Muamalat Indonesia (BMI), namun belum terwujud. 
Gambar. 1

Grafik Indeks Harga Saham PT Bank Panin Dubai

Syariah Tbk. 2014-2016

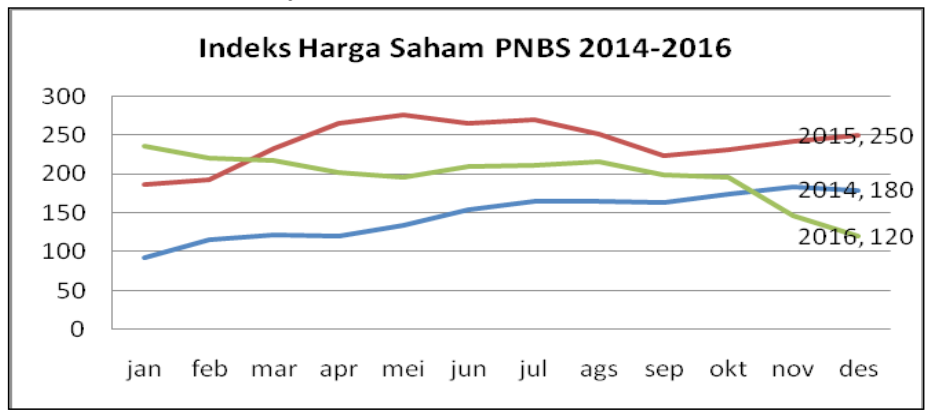

Sumber: finance.yahoo.com, diolah (2017).

Pada Desember 2015 indeks harga saham PT Bank Panin Dubai Syariah Tbk. menunjukkan perkembangan sangat baik pada level 250,00. Peningkatan ini sebagai hasil dari perkembangan keuangan syariah di Indonesia. Pertumbuhan ekonomi yang baik juga mendorong penguatan kinerja PT Bank Panin Dubai Syariah Tbk. ke arah positif. Dengan peningkatan tersebut, PT Bank Panin Dubai Syariah Tbk. akan mampu menarik minat investor untuk menanamkan modalnya pada PT Bank Panin Dubai Syariah Tbk. sehingga diharapkan berdampak pada peningkatan pertumbuhan ekonomi Indonesia. Namun pada Desember 2016 indeks harga saham PT Bank Panin Dubai Syariah Tbk. mengalami penurunan pada level 120,00. Hal ini diduga karena menurunnya tingkat kepercayaan investor akibat perubahan variabel makroekonomi sehingga mempengaruhi pergerakan saham PT Bank Panin Dubai Syariah Tbk. Hal ini menunjukkan sifat dinamik dari harga saham tersebut. Perubahan harga saham biasanya di pengaruhi oleh faktor internal maupun eksternal perusahaan.

Syahrir (1995) dalam bukunya Analisis Bursa Efek terdapat faktor yang berpengaruh pada indeks syariah yaitu variabel makroekonomi dan moneter seperti Sertifikat Bank Indonesia Syariah, inflasi, jumlah uang beredar, nilai tukar dan lainnya. Dari sisi internal yang berpengaruh adalah kondisi ekonomi nasional, keamanan, kondisi politik, kebijakan pemerintah dan lainnya (Ardana, 2016: 78). Dalam penelitian ini variabel makroekonomi 
yang digunakan yaitu tingkat inflasi, suku bunga BI, nilai tukar rupiah dan Sertifikat Bank Indonesia Syariah (SBIS).

Inflasi adalah kecenderungan meningkatnya harga barang dan jasa secara umum dan terus menerus (Kuncoro, 2015: 45). Inflasi yang tidak terkendali menyebabkan kenaikan harga secara umum dan mampu menurunkan keuntungan perusahaan, selain itu dapat menyebabkan kekacauan perekonomian dan perekonomian menjadi lesu. Menurunnya keuntungan perusahaan berpengaruh pada menurunnya harga saham perusahaan. Hal tersebut menjadi pertimbangan bagi investor dan memilih menahan diri agar tidak berinvestasi pada perusahaan yang terdaftar di pasar bursa sehingga hal tersebut berpengaruh pada permintaan saham Syariah.

Secara teori, tingkat bunga dan harga saham memiliki hubungan yang negatif. Tingkat bunga yang tinggi akan mempengaruhi nilai sekarang aliran kas perusahaan, sehingga peluang investasi tidak menarik lagi (Kewal, 2012: 53). Tingkat suku bunga BI memiliki pengaruh besar terhadap harga saham. Sehingga naiknya tingkat suku bunga BI menyebabkan harga saham turun dan menarik investor untuk menjual sahamnya. Hal ini tentu mempengaruhi harga saham. Tidak terkecuali saham syariah, meskipun secara prinsip tidak menggunakan instrument bunga dalam transaksi sahamnya.

Nilai tukar mempresentasikan tingkat harga pertukaran dari satu mata uang yang lainnya dan digunakan dalam berbagai transaksi (Al Arif, 2010: 107). Pada saat nilai tukar rupiah terdepresiasi, harga barang impor menjadi lebih mahal, khususnya bagi perusahaan yang bahan bakunya menggunakan barang impor. Nilai tukar rupiah mampu mempengaruhi pergerakan indeks harga saham pada pasar modal. Nilai tukar rupiah yang mengalami depresiasi akan memberikan dampak bagi perusahaan. Apabila keuntungan perusahaan turun maka mengakibatkan turunnya harga saham.

SBIS merupakan salah satu instrumen dibidang investasi syariah yang juga memberikan return dari hasil investasinya terhadap SBIS tersebut. Fluktuasi tingkat imbalan SBIS mempengaruhi bank syariah untuk berinvestasi di SBIS, dengan 
begitu bank syariah mendapatkan keuntungan dan bagi hasil pada nasabah tabungan atau deposito juga akan meningkat. Hal tersebut dapat mempengaruhi investor untuk beralih berinvestasi dibank syariah dibandingkan pasar modal.

Penelitian tentang kaitan kondisi makroekonomi terhadap aktivitas dan kinerja pasar modal telah banyak dilakukan sebelumnya. Diantaranya, penelitian yang dilakukan oleh Martien dan Nisful (2015) dengan menganalisis pengaruh inflasi, suku bunga BI dan nilai tukar rupiah terhadap pergerakan harga saham pada Indeks Saham Syariah Indonesia (ISSI) di BEI, hasil penelitian menunjukkan bahwa variabel inflasi dan suku bunga SBI berpengaruh tidak signifikan terhadap pergerakan harga saham ISSI sedangkan variabel nilai tukar rupiah berpengaruh secara signifikan terhadap pergerakan harga saham ISSI. Penelitian selanjutnya yang dilakukan oleh Maria, Topowijono dan Sri (2016) yang menganalisis pengaruh BI rate, niali tukar dan inflasi terhadap harga saham sub-sektor perbankan di BEI tahun 20112015, hasil penelitian menunjukkan bahwa variabel BI rate dan iflasi tidak berpengaruh signifikan terhadap harga saham perbankan sedangkan variabel niali tukar terdapat pengaruh signifikan terhadap harga saham perbankan.

Bank Panin Dubai Syariah Tbk saat ini masih menjadi single market di pasar saham keuangan syariah. Fakta ini menjadi keprihatianan tersendiri, ditengah semakin menggeliatnya industry saham secara global. Eksistensi Bank Panin Dubai Syariah,Tbk diharapkan mampu menarik perbankan syariah nasional yang lain untuk segera mengikuti jejaknya untuk melakukan listing pada pasar saham. Sebagai role model, maka diperlukan pengukuran dan evaluasi terhadap keterlibatan Bank Panin Dubai Syariah Tbk di pasar saham syariah.

Berdasarkan uraian tersebut, peneliti ingin mengetahui bagaimana pengaruh inflasi, suku bunga BI, nilai tukar rupiah dan SBIS terhadap indeks harga Saham PT Bank Panin Dubai Syariah Tbk. Selama periode januari 2014 sampai Desember 2016. 


\section{B. Kajian Pustaka}

\section{Indeks Harga Saham}

Indeks harga saham adalah indikator yang dapat digunakan oleh investor untuk mengetahui pergerakan pasar bursa. Dengan melihat angka indeks, maka kita dapat diketahuii apakah pergerakan pasar saat ini mengalami kenaikan atau penurunan dari kemarin. Indeks harga saham merupakan indikator yang menunjukkan pergerakan harga saham. Indeks berfungsi sebagai indikator tren pasar, artinya pergerakan indeks menggambarkan kondisi pasar pada suatu saat, apakah pasar sedang aktif atau lesu (Purwanta dan Fakhruddin, 2006: 46). Indeks harga saham adalah indikator utama yang menggambarkan pergerakan saham. Setidaknya indeks memiliki lima fungsi di pasar modal sebagai indikator, yaitu indikator tren saham, indikator tingkat keuntungan, tolok ukur kinerja suatu portofolio, memfasilitasi pembentukan portofolio dengan strategi pasif dan memfasilitasi berkembangnya produk derivative. (Umam, 2013: 137)

\section{Inflasi}

Definisi inflasi adalah kecenderungan peningkatan harga barang dan jsa secara umum dan terus menerus (Kuncoro, 2015: 45). Yang dimaksud dengan inflasi adalah proses kenaikan harga-harga umum barang-barang secara terus menrus. Ini tidak berarti bahwa harga-harga berbagai macam barang itu naik dengan prosentase yang sama. Mungkin dapat terjadi kenaikan tersebut tidaklah bersamaan. Yang penting terdapat kenaikan harga umum barang secara terus menerus selama suatu periode tertentu. Kenaikan yang terjadi hanya sekali saja (meskipun dengan presentase yang cukup besar) bukanlah merupakan inflasi. (Nopirin, 2014: 25)

\section{Suku Bunga Bank Indonesia}

Suku bunga adalah jumlah bunga yang dibayarkan per unit waktu yang disebut sebagai presentase dari jumlah yang dipinjamkan. Dengan kata lain, orang harus membayar kesempatan untuk meminjam uang (Samuelson dan Nordhaus, 2004: 190). Keynes membagi komponen kekayaan dalam dua bentuk, yakni 
uang kas dan surat berharga. Kekayaan dalam surat bentuk berharga, dimana harganya dapat naik turun tergantung dari tingkat bunga (apabila tingkat bunga naik, harga surat berharga turun dan sebaliknya), sehingga ada kemungkinan pemegang surat berharga akan menderita capital loss atau gain. Namun demikian, surat berharga mendatangkan pendapatan yang berupa bunga. Dengan anggapan bahwa masyarakat tidak suka risiko maka mereka memilih memegang bentuk kekayaan yang beresiko tinggi (surat berharga) apabila didorong dengan tingkat bunga yang tinggi pula. Semakin banyak surat berharga dalam kekayaan, risikonya juga semakin tinggi. Oleh karena itu harus didorong dengan tingkat bunga yang lebih tinggi pula. Tingkat bunga di sini adalah tingkat bunga "rata-rata" dari segala macam surat berharga yang beredar di masyarakat. (Nopirin, 2000: 94-95)

\section{Nilai Tukar Rupiah}

Kurs valuta asing atau kurs mata uang asing menunjukkan harga atau nilai mata uang suatu negara dinyatakan dalam nilai mata uang negara lain.kurs valuta asing dapat juga didefinisikan sebagai jumlah uang domestik yang dibutuhkan, yaitu banyaknya rupiah yang dibutuhkan ubtuk memperoleh satu unit mata uang asing (Sukirno, 2015: 397). Exchange rates (nilai tukar uang) atau yang lebih populer dikenal dengan sebutan kurs mata uang adalah catatan harga pasar dari mata uang asing dalam mata uang domestik begitu pula sebaliknya, yaitu harga mata uang domestik dalam mata uang asing. Nilai tukar uang mempresentasikan tingkat harga pertukaran mata uang yang lainnya dan digunakan dalam berbagai transaksi, antara lain transaksi perdagangan internasional, investasi internasional ataupun aliran uang jangka pendek antar negara yng melewati batas geografis ataupun batas hukum. (Al Arif, 2010: 107)

\section{Sertifikat Bank Indonesia Syariah}

Dalam rangka realisasi pengendalian moneter Bank Indonesia menggunakan instrumen moneter yang terdiri dari cadangan wajib minimum, tingkat bunga diskonto dan operasi pasar terbuka. Dalam operasi pasar terbuka Bank Indonesia melakukan transaksi jual beli surat berharga termasuk didalamnya Sertifikat 
Bank Indonesia Syariah (SBIS) (Suciningtyas dan Khoiroh, 2015: 401). Sertifikat Bank Indonesia Syariah (SBIS) adalah surat berharga berdasarkan prinsip syariah berjangka waktu pendek dalam mata uang rupiah yang diterbitkan oleh Bank Indonesia. (PBI No.10/11/ PBI/2008 pasa1 1 ayat 4). SBIS diterbitkan oleh Bank Indonesia sebagai salah satu instrumen operasi pasar terbuka dalam rangka pengendalian moneter yang dilakukan berdasarkan prinsip syariah (PBI No. 10/11/PBI/2008 pasal 2).

\section{Metode Penelitian}

\section{Jenis Penelitian}

Dalam penelitian ini, penulis menggunakan metode penelitian kuantitatif. Sumber data yang digunakan adalah data sekunder. Data sekunder merupakan data yang diperoleh secara tidak langsung misalnya melalui dokumen. Teknik dokumentasi yang digunakan dalam penelitian ini berupa pencarian data berupa laporan indeks harga saham PT Bank Panin Dubai Syariah Tbk., laporan publikasi inflasi, suku bunga BI, nilai tukar rupiah dan tingkat imbalan SBIS tahun 2014-2016. Metode yang digunakan dalam pengumpulan data dilakukan secara online, yaitu dengan mengakses finance.yahoo.com (laporan indeks harga saham PT Bank Panin Dubai Syariah) dan www.bi.go.id (laporan inflasi, suku bunga BI, nilai tukar rupiah dan tingkat imbalan SBIS).

\section{Populasi dan Sampel}

Populasi yang digunakan dalam penelitian ini adalah data indeks harga saham bank syariah yang sahamnya terdaftar dalam ISSI, inflasi, suku bunga BI, nilai tukar rupiah dan Sertifikat Bank Indonesia Syariah (SBIS). Dari 331 perusahaan yang terdaftar dalam ISSI hanya ada satu perusahaan yang memenuhi syarat yaitu PT Bank Panin Dubai Syariah.

Teknik sampel yang digunakan dalam penelitian adalah teknik sampling jenuh. Data yang digunakan sebagai sampel adalah harga penutupan/closing price indeks harga saham PT Bank Panin Dubai Syariah Tbk., data inflasi, data suku bunga BI, data nilai tukar rupiah dan data tingkat imbalan Sertifikat Bank Indonesia Syariah (SBIS). Semua data variabel penelitian menggunakan data bulanan, 
sehingga diperoleh data sebanyak 36 periode mulai Januari 2014 sampai Desember 2016. Sebagai informasi, mulai tanggal 19 Agustus 2016 Bank Indonesia menyatakan bahwa suku bunga acuan BI tidak lagi menggunakan BI Rate dan diganti dengan 7 Days Reverse Repo Rate. Hal tersebut bertujuan agar suku bunga kebijakan dapat secara cepat mempengaruhi pasar uang, perbankan dan sektor riil.

\section{Teknik Analisis Data}

Teknik analisis data yang digunakan dalam penelitian ini adalah dengan analisis regresi linier berganda dengan tujuan untuk mengetahui seberapa besar pengaruh variabel independen terhadap variabel dependen. Urutan teknik analisis data yang digunakan yaitu uji asumsi klasik, uji ketepatan model, analisis regresi linier berganda dan uji t. Uji asumsi klasik terdiri dari uji normlitas, uji autokorelasi, uji multikolinieritas dan uji heteroskedastisitas. Uji ketepatan model terdIri dari koefisien determinasi dan uji F. Alat analisis menggunakan aplikasi Eviews 9.

\section{Hasil Pembahasan}

\section{Analisis Regresi Linier Berganda}

Analisis regresi linier berganda digunakan untuk menganalisis pengaruh variabel bebas inflasi, suku bunga BI, nilai tukar rupiah dan SBIS terhadap variabel terikat indeks harga saham PT Bank Panin Dubai Syariah Tbk. Nilai koefisien regresi tiap variabel dapat dilihat dari nilai coefficient pada tabel. Hasil analisis regresi linier berganda dapat dilihat sebagai berikut:

Tabel. 2

Output Analisis Regresi Linier Berganda

\begin{tabular}{lcccc}
\hline \multicolumn{1}{c}{ Variable } & Coefficient & Std. Error & t-Statistic & Prob. \\
\hline C & -8.110117 & 2.119499 & -3.826432 & $0.0006^{* *}$ \\
\hline INFLASI & -0.208831 & 0.106309 & -1.964376 & $0.0585^{* *}$ \\
\hline SUKU_BUNGA_BI & 1.894225 & 0.389747 & 4.860134 & $0.0000^{* *}$ \\
\hline NILAI_TUKAR_RUPIAH & 2.828081 & 0.453002 & 6.242982 & $0.0000^{* *}$ \\
\hline SBIS & -3.222594 & 0.997012 & -3.232250 & $0.0029^{* *}$ \\
\hline
\end{tabular}

Sumber : data diolah, 2017.

Keterangan: * sig. pada $\alpha=1 \%{ }^{* *}$ sig. pada $\alpha=5 \% \quad{ }^{* * *}$ sig. pada $\alpha=10 \%$ 
Berdasarkan tabel. 2 di atas persamaan regresi linier berganda dapat disusun sebagai berikut:

$$
Y=-8,110-0,209 X_{1}+1,894 X_{2}+2,828 X_{3}-3,223 X_{4}+e
$$

Berdasarkan persamaan regresi linier berganda dapat diinterprestasikan sebagai berikut:

a. Konstanta bernilai negatif sebesar 8,110, hal ini menunjukkan bahwa apabila variabel inflasi, suku bunga BI, nilai tukar rupiah dan SBIS jika dianggap konstan (0), maka nilai indeks harga saham PT. Bank Panin Dubai Syariah Tbk. turun sebesar 8,110.

b. Koefisien regresi variabel inflasi $(\beta 1)$ bernilai negatif sebesar 0,209 , hal ini berarti bahwa jika inflasi ditingkatkan $1 \%$ dengan catatan variabel suku bunga BI, nilai tukar rupiah dan SBIS dianggap konstan maka akan menurunkan nilai indeks harga saham PT. Bank Panin Dubai Syariah Tbk. sebesar 0,209.

c. Koefisien regresi variabel suku bunga BI ( $\beta 2)$ bernilai positif sebesar 1,894, hal ini berarti bahwa jika suku bunga BI ditingkatkan $1 \%$ dengan catatan variabel inflasi, nilai tukar rupiah dan SBIS dianggap kosntas maka akan meningkatkan nilai indeks harga saham PT. Bank Panin Dubai Syariah Tbk. sebesar 1,894 .

d. Koefisien regresi variabel nilai tukar rupiah ( $\beta 3)$ bernilai positif sebesar 2,828, hal ini berarti bahwa jika nilai tukar rupiah ditingkatkan $1 \%$ dengan catatan inflasi, suku bunga BI dan SBIS dianggap konstan maka akan meningkatkan nilai indeks harga saham PT. Bank Panin Dubai Syariah Tbk. sebesar 2,828.

e. Koefisien regresi variabel SBIS ( $\beta 4$ ) bernilai negatif sebesar 3,223, hal ini berarti bahwa jika SBIS ditingkatkan 1\% dengan catatan inflasi, suku bunga BI dan nilai tukar rupiah dianggap konstan maka akan menurunkan nilai indeks harga saham PT. Bank Panin Dubai Syariah Tbk. sebesar 3,223. 


\section{Uji Hipotesis (Uji t)}

Uji t digunakan untuk menguji pengaruh variabel independen (inflasi, suku bunga BI, nilai tukar rupiah dan SBIS) secara parsial terhadap variabel dependen indeks harga saham PT. Bank Panin Dubai Syariah Tbk. Hasil uji t dapat dilihat pada nilai prob. thitung (ditunjukkan pada Prob.) pada tabel 4.6. Apabila prob. $t$ hitung lebih kecil dari $\alpha=5 \%$ maka variabel bebas berpengaruh signifikan terhadap variabel terikatnya, sedangkan apabila nilai prob. t hitung lebih besar dari $a=5 \%$ maka dapat dikatakan bahwa variabel bebas tidak berpengaruh signifikan terhadap variabel terikatnya. Berdasarkan hasil uji t pada tabel 4.6 dapat diinterprestasikan:

a. Variabel inflasi diperoleh nilai prob. $t$ hitung sebesar 0,0585 , jika dibandingkan dengan $a=5 \%$ maka prob. $t$ hitung $>$ $\mathrm{a}=5 \%$. Hal ini menunjukkan bahwa $\mathrm{H}_{0}$ diterima, artinya inflasi tidak berpengaruh signifikan terhadap indeks harga saham bank PT. Bank Panin Dubai Syariah Tbk.

b. Variabel suku bunga BI diperoleh nilai prob. t hitung sebesar 0,0000, jika dibandingkan dengan $a=5 \%$ maka prob. $t$ hitung $<\mathrm{a}=5 \%$. Hal ini menunjukkan bahwa $\mathrm{H}_{1}$ diterima, artinya suku bunga BI berpengaruh signifikan terhadap indeks harga saham PT. Bank Panin Dubai Syariah Tbk.

c. Variabel nilai tukar rupiah diperoleh nilai prob. $\mathrm{t}$ hitung sebesar 0,0000, jika dibandingkan dengan $a=5 \%$ maka prob. t hitung $<\mathrm{a}=5 \%$. Hal ini menunjukkan bahwa $\mathrm{H}_{1}$ diterima, artinya nilai tukar rupiah berpengaruh signifikan terhadap indeks harga saham PT. Bank Panin Dubai Syariah Tbk.

d. Variabel SBIS diperoleh nilai prob. $t$ hitung sebesar 0,0029, jika dibandingkan dengan $\mathrm{a}=5 \%$ maka prob. $\mathrm{t}$ hitung < $\mathrm{a}=5 \%$. Hal ini menunjukkan bahwa $\mathrm{H}_{1}$ diterima, artinya SBIS berpengaruh signifikan terhadap indeks harga saham PT. Bank Panin Dubai Syariah Tbk. 


\section{E. Analisis Data}

1. Inflasi tidak berpengaruh signifikan terhadap indeks harga saham PT. Bank Panin Dubai Syariah Tbk.

Inflasi tidak berpengaruh signifikan terhadap indeks harga saham PT. Bank Panin Dubai Syariah Tbk. Hal ini dinyatakan berdasarkan hasil uji $t$ variabel inflasi dengan nilai prob. $t$ hitung $(0,0585)>a(5 \%)$. Dalam penelitian ini inflasi tidak berpengaruh terhadap indeks harga saham bank syariah artinya naik turunnya inflasi tidak terlalu mempengaruhi indeks harga saham bank syariah.

Hasil penelitian ini berbeda dengan teori yang digunakan dalam penelitian ini yaitu inflasi yang tinggi menyebabkan turunnya profitabilitas suatu perusahaan sehingga akan menurunkan pembagian deviden dan daya beli masyarakat juga menurun. Sehingga inflasi yang tinggi mempunyai hubungan negatif dengan pasar ekuitas atau harga saham perusahaan (Sunariyah, 2006: 22). Hasil penelitian ini mendukung hasil penelitian sebelumnya yang dilakukan Kewal (2012) yaitu menunjukkan bahwa secra parsial tingkat inflasi tidak memiliki pengaruh yang signifikan terhadap IHSG. hasil penelitian berbeda disampaikan Suciningtyas dan Khoiroh (2015) yang menyatakan bahwa inflasi berpengaruh terhadap indeks harga saham.

\section{Suku bunga BI berpengaruh signifikan terhadap indeks harga saham PT. Bank Panin Dubai Syariah Tbk.}

Suku bunga BI berpengaruh signifikan terhadap indeks harga PT. Bank Panin Dubai Syariah Tbk. Hal ini dinyatakan berdasarkan hasil uji $t$ variabel suku bunga $B I$ dengan nilai prob. $t$ hitung $(0,0000)<\alpha(5 \%)$. Dalam penelitian ni besarnya suku bunga BI yang ditetapkan mempengaruhi indeks harga saham bank syariah.

Hasil penelitian ini mendukung teori yang digunakan yaitu meningkatnya tingkat bunga akan meningkatkan harga kapital sehingga memperbesar biaya perusahaan, sehingga perpindahan investasi dari saham ke deposito atau fixed investasi lainnya. Apabila faktor-faktor lain dianggap tetap (cateris paribus) profitabilitas perusahaan akan menurun. Tngkat bunga yang tinggi adalah signal 
negatif bagi harga saham (Sunariyah, 2006: 22). Hasil penelitian ini mendukung hasil penelitian Ardana (2016) yaitu menyatakan dalam jangka panjang terdapat hubungan negatif antara suku bunga BI dengan ISSI. hasil penelitian berbeda disampaikan oleh Kewal (2012) bahwa secara parsial variabel suku bunga BI tidak berpengaruh signifikan terhadap IHSG.

\section{Nilai tukar rupiah berpengaruh signifikan terhadap indeks harga saham PT Bank Panin Dubai Syariah Tbk.}

Nilai tukar rupiah berpengaruh signifikan terhadap indeks harga saham PT Bank Panin Dubai Syariah Tbk. Hal ini dinyatakan berdasarkan hasil uji t variabel nilai tukar rupiah dengan nilai prob. thitung $(0,0000)<\alpha(5 \%)$. Dalam penelitian ini menunjukkan bahwa nilai tukar rupiah terhadap USD yang ditetapkan mempengaruhi indeks harga saham bank syariah.

Hasil penelitian ini mendukung teori yang digunakan yaitu menurunnya kurs dapat meningkatkan biaya impor bahan baku dan meningkatkan suku bunga walaupun dapat meningkatkan nilai ekspor. Menurunnya kurs rupiah terhadap mata uang asing memiliki pengaruh negatif terhadap ekonomi dan pasar modal atau harga saham (Sunariyah, 2006:22). Hasil penelitian ini mendukung hasil penelitian Kewal (2012) yang menyatakan bahwa kurs rupiah terhadap dollar AS memiliki pengaruh negatif dan signifikan terhadap IHSG. berbeda dengan hasil penelitian Saputra dan Herlambang (2014) yang menyatakan bahwa kurs rupiah berpengaruh parsial terhadap ISSI dan pengaruh tersebut menunjukkan ke arah positif.

\section{SBIS berpengaruh signifikan terhadap indeks harga saham PT Bank Panin Dubai Syariah Tbk.}

SBIS berpengaruh signifikan terhadap indeks harga saham PT Bank Panin Dubai Syariah Tbk. Hal ini dinyatakan berdasarkan hasil uji t variabel SBIS dengan nilai prob. $t$ hitung $(0,0029)<\alpha(5 \%)$. Dalam penelitian ini menunjukkan bahwa tingkat imbalan SBIS yang diberiakn BI untuk bank syariah yang ikut serta dalam SBIS mempunyai pengaruh terhadap indeks harga saham bank syariah. 
Hal tersebut sesuai dengan teori dalam penelitian ini yaitu ketika imbalan yang diperoleh bank syariah dalam melakukan investasi SBIS besar maka bank syariah memperoleh keuntungan, sehingga return yang diberikan kepada nasabah yang menabung menyebabkan deposito tinggi. Hal tersebut nanpu menarik investor untuk berinvesatsi di bank syariah. Ketika minat investor turun di pasar modal syariah tentu hal tersebut dapat memicu menurunnya indeks harga saham. Hasil penelitian ini mendukung hasil penelitian Ardana (2016) menyatakn variabel SBIS mempunyai pengaruh signifikan dan mempunyai hubungan jangka pendek demham ISSI serta mempunyai hubungan jangka panjanh positif terhadap ISSI. sama dengan hasil penelitian Suciningtyas dan Khoiroh (2015) bahwa variabel SBIS mempunyai pengaruh tidak signifikan terhadap ISSI dan tingkat imbalan SBIS mempengaruhi secara kuat pergerakan ISSI.

\section{F. Simpulan}

Berdasarkan hasil penelitian mengenai pengaruh inflasi, suku bunga BI, niali tukar rupiah dan Sertifikat Bank Indonesia Syariah (SBIS) terhadap indeks harga saham PT Bank Panin Dubai Syariah Tbk. tahun 2014-2016, dapat ditarik kesimpulan sebagai berikut:

1. Inflasi tidak berpengaruh signifikan terhadap indeks harga saham PT. Bank Panin Dubai Syariah Tbk. Hal ini dinyatakan berdasarkan hasil uji $\mathrm{t}$ variabel inflasi dengan nilai prob. $\mathrm{t}$ hitung $(0,0585)>a(5 \%)$.

2. Suku bunga BI berpengaruh signifikan terhadap indeks harga saham PT. Bank Panin Dubai Syariah Tbk. Hal ini dinyatakan berdasarkan hasil uji $\mathrm{t}$ variabel suku bunga BI dengan nilai prob. $t$ hitung $(0,0000)<\alpha(5 \%)$.

3. Nilai tukar rupiah berpengaruh signifikan terhadap indeks harga saham PT Bank Panin Dubai Syariah Tbk. Hal ini dinyatakan berdasarkan hasil uji t variabel nilai tukar rupiah dengan nilai prob. $t$ hitung $(0,0000)<\alpha(5 \%)$.

4. SBIS berpengaruh signifikan terhadap indeks harga saham PT Bank Panin Dubai Syariah Tbk. Hal ini dinyatakan berdasarkan hasil uji $\mathrm{t}$ variabel SBIS dengan nilai prob. $\mathrm{t}$ hitung $(0,0029)<a(5 \%)$. 


\section{DAFTAR PUSTAKA}

Al Arif, M. Nur Rianto. 2010. Teori Makroekonomi Islam: Konsep, Teori, dan Analisis. Bandung: Alfabeta.

Ardana, Yudhistira. 2016. Analisis Pengaruh Variabel Makroekonomi terhadap Indeks Saham Syariah Indonesia (Periode Mei 2011-September 2015 dengan Metode ECM).Jurnal ekonomi, Bisnis \& Enterpreneurship, Vol. 10, No. 1, 76-90.

Bank Indonesia. Penjalasan tentang BI Rate. http://www.bi.go.id/ id/moneter/ bi-r ate/penjelasan/Contents/Default.aspx diakses 30 Januari 2017 pukul 09.40.

Bank Indonesia. Data Inflasi Tahun 2014-2016. http://www.bi.go. $\mathrm{id} / \mathrm{id} /$ moneter/ inflasi/data/Default.aspx diakses pada 30 Januari 2017 pukul 09.40.

Bank Indonesia. Data BI Rate Tahun 2014-2016. http://www.bi.go. $\mathrm{id} / \mathrm{id} / \mathrm{moneter} /$ bi-rate/data/Default.aspx diakses pada 30 Januari 201709.42.

Bank Indonesia. Data BI Rate Tahun 2014-2016. http://www.bi.go. $\mathrm{id} / \mathrm{id} /$ moneter /bi-7day-RR/data/Contents/Default.aspx diakses pada 30 Januari 201709.42.

Bank Indonesia. Kalkulator Kurs Tahun 2014-2016. http://www. bi.go.id/id/ moneter/kal kulator-kurs/Default.aspx diakses 30 Januari 2017 pukul 09.47.

Bank Indonesia. Data Lelang Sertifikat Bank Indonesia Syariah. http:/ / www.bi. go.id/id/moneter/operasi/lelang-sbi/Default. aspx diakses 30 Januari 2017 pukul 09.49.

Beik, Irfan Syauqi dan Fatmawati, Sri Wulan. 2014. Pengaruh Indeks Harga Saham Syariah Internasional dan Variabel Makroekonomi terhadap Jakarta Islamic Index. Journal of Islamic Economic, Vol. 6, No. 2, 155-158.

Ginting, Maria R.M., Topowijono dan Sulasmiyati, Sri. Saham 2016. Pengaruh Tingkat Suku Bunga, Nilai Tukar dan Inflasi terhadap Harga Saham (Studi pada Sub-Sektor Perbankan di 
Bursa Efek Indonesia Periode 2011-2015). Jurnal Administrasi Bisnis. Vol. 35, No. 2, 77-85.

Kewal, Suramaya Suci. 2012. Pengaruh Inflasi, Suku Bunga, Kurs, dan Pertumbuhan PDB terhadap Indeks Harga Saham Gabungan. Jurnal Economia, Vol. 8, No. 1, 53-64.

Kuncoro, Mudrajat. 2015. Mudah Memahami dan Menganalisis: Indikator Ekonomi. Cet. ke-2. Yogyakarta: UPP STIM YKPN.

Nopirin. (2000). Ekonomi Moneter Buku II. Yogyakarta: BPFE. 2014. Ekonomi Moneter Buku 2. Yogyakarta: BPFE

PBI no. 10/11/PBI/ 2008 tentang Sertifikat Bank Indonesia Syariah Purwanta, Wiji dan Fakhruddin, Hendy. (2006). Mengenal Pasar modal. Jakarta: Salemba Empat.

Rachmawati, Martien dan Laila, Nisful. Saham. 2015. Faktor Makroekonomi yang Mempengaruhi Pergerakan Harga Saham pada Indeks Harga Saham Syariah Indonesia (ISSI) di Bursa Efek Indonesia (BEI). Jurnal Ekonomi Syariah Teori dan Terapan. Vol. 2, No. 11, 928-942.

Samuelson, Paul. A. dan Nordhaus, William. D. 2004. Ilmu Makroekonomi Ed. Ketujuhbelas. Jakarta: PT Media Global Edukasi.

Saputra, Imam Dwi dan Herlambang, Leo. 2014. Pengaruh Kurs Rupiah terhadap Indeks Harga Saham (Studi Pada Indeks Harga Saham Syariah Indonesia Periode 2011-2013). Jurnal Ekonomi Syariah Teori dan Terapan, Vol. 1, No. 12, 832-840.

Suciningtyas, Siti Aisiyah dan Khoiroh, Rizki. 2015. Analisis Dampak Variabel Makroekonomi terhadap Indeks Saham Syariah Indonesia. Conference of Business, Accounting, and Managemen. Vol. 2, No. 1, 398-412.

Umam, Khaerul. 2013. Pasar Modal Syariah dan Praktik Pasar Modal Syariah. Bandung: Pustaka Setia.

Yahoo! Finance. Data Historis Saham Bank Panin Dubai Syariah. https: / / finance.yahoo.com/q/ hp? $\mathrm{a}=00 \& \mathrm{~b}=1 \& \mathrm{c}=2014 \& \mathrm{~d}=$ $11 \& \mathrm{e}=31 \& \mathrm{f}=2016 \& \mathrm{~g}=\mathrm{m} \& \mathrm{~s}=\mathrm{PNBS} . \mathrm{JK} \% 2 \mathrm{C}+\& \mathrm{ql}=1$ diakses 30 Januari 2017 pukul 10.05 . 